\title{
Discover our content and keep your practice current
}

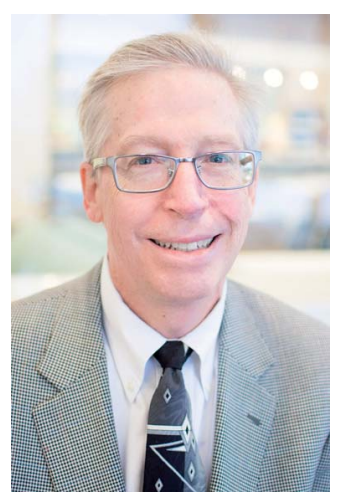

$\mathrm{O}$

ver the past 5 years, Neurology: Clinical Practice (NCP) has strived to evolve from a useful peer-reviewed resource for the practicing general neurologist to an indispensable point-of-care tool both for the general neurologist and the subspecialist in practice seeking to optimize patient care. While we anticipated being well-received by our US audience, we have been surprised and heartened by our international reach.

The data tell us that readers increasingly are discovering our content through targeted searches on the Web. We have reclassified our content so that however you reach an article in NCP, you will know what you're getting: Research, Review, Commentary, or Case. We have also introduced structured Abstracts for Research and Review articles and encouraged our authors to provide take-home points for the reader.

A new feature led by Section Editor Luca Bartolini, MD, encourages sharing of best practices among our readers (see the Editorial on p. 14 for details). "Practice Current: An interactive exchange on controversial topics" was designed to offer a unique perspective on how neurologists at different stages of their careers and in different areas of the world approach the same clinical scenario.

As Drs. Bartolini and Millichap observe, "There is no single correct answer to the clinical questions presented in Practice Current; instead, this is an opportunity for the readers to share their experience, learn from each other and from the experts, and potentially build consensus."

As always, we welcome your feedback on this issue and invite suggestions for improving NCP.
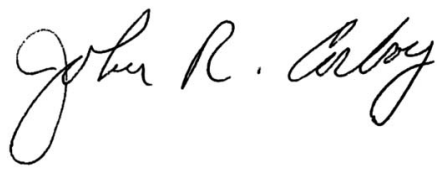

John R. Corboy, MD, FAAN 


\title{
Neurology ${ }^{\circ}$ Clinical Practice
}

\author{
Discover our content and keep your practice current \\ Neurol Clin Pract 2016;6;1 \\ DOI 10.1212/CPJ.0000000000000222
}

This information is current as of February 15, 2016

\section{Updated Information \& Services}

Subspecialty Collections

Permissions \& Licensing

Reprints including high resolution figures, can be found at:

http://cp.neurology.org/content/6/1/1.full.html

This article, along with others on similar topics, appears in the following collection(s):

\section{All Immunology}

http://cp.neurology.org//cgi/collection/all_immunology

Encephalitis

http://cp.neurology.org//cgi/collection/encephalitis

Information about reproducing this article in parts (figures,tables) or in its entirety can be found online at:

http://cp.neurology.org/misc/about.xhtml\#permissions

Information about ordering reprints can be found online: http://cp.neurology.org/misc/addir.xhtml\#reprintsus

Neurol Clin Pract is an official journal of the American Academy of Neurology. Published continuously since 2011, it is now a bimonthly with 6 issues per year. Copyright (C) 2015 American Academy of Neurology. All rights reserved. Print ISSN: 2163-0402. Online ISSN: 2163-0933.

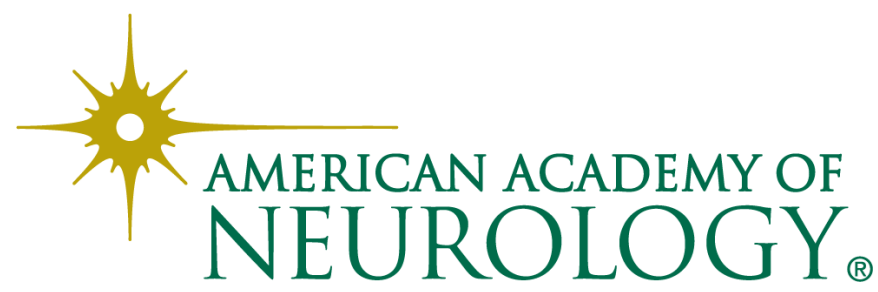

